\title{
FAKTOR-FAKTOR YANG MEMPENGARUHI AUDIT DELAY PADA PERUSAHAAN PERTAMBANGAN YANG TERDAFTAR DI BURSA EFEK INDONESIA
}

\author{
ROMASI LUMBAN GAOL ${ }^{1}$ \\ KRISTA SRIKANDI DUHA ${ }^{2}$ \\ ${ }^{1,2}$ Fakultas Ekonomi Program Studi Akuntansi Universitas Katolik Santo Thomas \\ romasilumbangaol@yahoo.co.id kristasrikandi@gmail.com
}

\begin{abstract}
ABSTRAK
Penelitian ini bertujuan untuk menganalisis pengaruh opini auditor, profitabilitas, dan ukuran perusahaan terhadap audit delay pada perusahaan pertambangan yang terdaftar di Bursa Efek Indonesia (BEI). Sampel pada penelitian ini didapatkan dengan cara purposive sampling, dengan jumlah sampel 36 perusahaan. Dari hasil pengujian diketahui bahwa, nilai koefisien determinasi ( $R$ Square) sebesar 0,356 ini berarti bahwa opini auditor, profitabilitas dan ukuran perusahaan secara bersama-sama mempengaruhi audit delay sebesar 35,6\%. Berdasarkan hasil uji parsial dapat disimpulkan bahwa opini auditor dan profitabilitas berpengaruh negatif dan signifikan terhadap audit delay. Sedangkan ukuran perusahaan berpengaruh positif dan signifikan terhadap audit delay.
\end{abstract}

Kata kunci: audit delay, opini auditor, profitabilitas dan ukuran perusahaan

\section{PENDAHULUAN}

Perusahaan yang terdaftar di Bursa Efek Indonesia setiap tahun diwajibkan untuk menyampaikan laporan tahunan (annual report) yang sudah diaudit kepada para pemodal (stockholder). Tujuannya untuk memberikan informasi tentang entitas yang berguna dalam pengambilan keputusan.

Menurut Peraturan Otoritas Jasa Keuangan Nomor 29/POJK.04/2016 tentang Laporan Tahunan Emiten Atau Perusahaan Publik pasal 7 ayat 1 bahwa "Emiten atau Perusahaan Publik wajib menyampaikan Laporan Tahunan kepada Otoritas Jasa Keuangan paling lambat pada akhir bulan keempat setelah tahun buku berakhir." Jika perusahaan atau emiten yang bersangkutan tidak melakukan seperti hal tersebut maka yang bersangkutan akan diberi sanksi oleh Otoritas Jasa Keuangan (OJK) yakni a). peringatan tertulis; b). denda yaitu kewajiban untuk membayar sejumlah uang tertentu; c). Pembatasan kegiatan usaha; d). Pembekuan kegiatan usaha; e) .pencabutan izin usaha; f). Pembatalan persetujuan; g). Pembatalan pendaftaran.

Untuk menghindari sanksi dari keterlambatan penyampaian laporan keuangan, maka rentang waktu penyelesaian audit oleh auditor harus sesuai dengan peraturan yang ditetapkan oleh OJK. Adapun rentang waktu penyelesaian audit oleh auditor terlihat dari perbedaan waktu antara tanggal laporan keuangan dengan tanggal opini audit dalam laporan keuangan auditan.

Febrianty dalam Kurniawan \& Henry (2015:2) menyatakan perbedaan waktu tersebut disebut audit delay. Menurut Apriliane (2015:43), audit delay adalah lamanya hari yang dibutuhkan auditor untuk menyelesaikan pekerjaan auditnya, yang diukur dari tanggal penutupan tahun buku hingga tanggal diterbitkannya laporan keuangan audit. Semakin lama auditor menyelesaikan pekerjaan auditnya, maka semakin lama pula audit delay. Jika audit delay semakin lama, maka kemungkinan keterlambatan penyampaian laporan keuangan akan semakin besar. Oleh karena itu penelitian mengenai audit delay menjadi objek yang tepat untuk mencari bukti empiris mengenai faktor-faktor yang berpengaruh terhadap audit delay.

Beberapa faktor-faktor yang kemungkinan dapat mempengaruhi audit delay yaitu: Ukuran perusahaan, profitabilitas, dan opini auditor. Perusahaan besar diduga akan menyelesaikan proses auditnya lebih cepat dibandingkan perusahaan kecil. Hal ini disebabkan oleh beberapa faktor yaitu manajemen perusahaan yang berskala besar cenderung diberikan insentif untuk mengurangi audit delay dikarenakan perusahaan-perusahaan tersebut dimonitor secara ketat oleh investor, pengawas permodalan dari pemerintah (Dyer dan Mc Hugh,1975).

Profitabilitas adalah kemampuan perusahaan untuk menghasilkan keuntungan (Murhadi, 2013). Perusahaan yang mampu menghasilkan profit akan cenderung mengalami audit delay yang 
lebih pendek, sehingga good news tersebut dapat segera disampaikan kepada para investor dan pihak-pihak yang berkepentingan lainnya (Kartika: 2011).

Opini audit merupakan pendapat atas kewajaran laporan keuangan yang diauditnya (Apriliane, 2015). Mumpuni dalam Kurniawan \& Laksito (2015) menyatakan bahwa perusahaan yang menerima pendapat selain unqualified opinion membutuhkan waktu audit yang lebih lama dari pada perusahaan yang mendapatkan unqualified opinion. Hal ini terjadi karena pemberian pendapat selain unqualified opinion memerlukan negosisasi dengan klien serta konsultasi dengan partner audit, apabila auditor menemukan penyimpangan terhadap PABU (Prinsip Akuntansi Berterima Umum). Selain itu, auditor juga dituntut untuk menemukan penyimpangan dan disertai dengan bukti-bukti yang dapat mendukung temuannya.

Objek dalam penelitian ini adalah perusahaan pertambangan yang terdaftar di Bursa Efek Indonesia periode 2016-2018. Peneliti memilih perusahaan pertambangan sebagai objek penelitian karena sektor ini merupakan salah satu yang sebenarnya memiliki pertumbuhan indeks saham yang cukup menjanjikan tiap tahunnya. Dikutip dari website www.kontan.co.id (2018) menyebutkan bahwa berdasarkan data Bloomberg, indeks saham konstruksi, pertambangan tumbuh 26 persen dalam 12 tahun terakhir, angka tersebut dua kali lipat dari IHSG. Peningkatan laba kumulatif sektor mining mencapai di atas 100 persen, disebabkan oleh meningkatnya laba perusahaan tercatat pada sub-sektor pertambangan batubara.

Berdasarkan penjelasan yang dikemukakan diatas, maka masalah dirumuskan dalam bentuk pertanyaan sebagai berikut: "Apakah profitabilitas, ukuran perusahaan, dan opini audit mempunyai pengaruh terhadap audit delay pada perusahaan pertambangan yang terdafta di Bursa Efek Indonesia?".

\section{DASAR TEORI}

\section{Agency Theory (Teori Keagenan)}

Agency Theory (Teori Keagenan) merupakan hubungan antar agen (pihak manajemen suatu perusahaan) dengan principal (pemilik). Situmorang (2017) menyatakan teori keagenan dilandasi oleh beberapa asumsi yang terdiri dari tiga jenis, yaitu asumsi tentang sifat manusia, asumsi keorganisasian dan asumsi informasi.

Asumsi sifat manusia menekankan bahwa manusia memiliki sifat mementingkan diri sendiri (self interest), Asumsi keorganisasian adalah adanya konflik antar anggota organisasi, efisiensi sebagai kriteria efektivitas dan adanya asimetri informasi antara principal dan agent. Konflik kepentingan dalam asumsi informasi dapat menimbulkan asimetri informasi.

Menurut Lestari (2010: 10) Asimetri informasi dimaknai sebagai ketidakseimbangan informasi akibat distribusi informasi yang tidak sama antara agen dengan principal. Dalam teori agensi, auditor independen berperan sebagai penengah kedua belah pihak (Situmorang, 2017:13). Auditor merupakan pihak yang diyakini mampu menjembatani kepentingan antara pihak prinsipal dengan agen dalam mengelola keuangan perusahaan.

\section{Teori Kepatuhan (Compliance Theory)}

Teori kepatuhan dapat mendorong seseorang untuk lebih mematuhi peraturan yang berlaku, sama halnya dengan perusahaan yang berusaha untuk menyampaikan laporan keuangan tepat waktu karena merupakan kewajiban perusahaan untuk menyampaikan laporan keuangan tepat waktu, dan juga akan sangat bermanfaat bagi para pengguna laporan keuangan. Situmorang (2017: 14) menyatakan berdasarkan perspektif normatif maka sudah seharusnya bahwa teori kepatuhan ini dapat diterapkan di bidang Akuntansi.

\section{Audit Delay}

Menurut Apriliane (2015:43), audit delay adalah lamanya hari yang dibutuhkan auditor untuk menyelesaikan pekerjaan auditnya, yang diukur dari tanggal penutupan tahun buku hingga tanggal diterbitkannya laporan keuangan audit.

Menurut penelitian Owusu-Ansah dalam Kartika (2011), semakin panjang waktu yang dibutuhkan di dalam mempublikasikan laporan keuangan tahunan sejak akhir tahun buku suatu 
perusahaan milik klien, maka semakin besar pula kemungkinan informasi tersebut bocor kepada investor tertentu atau bahkan bisa menyebabkan insider trading dan rumor-rumor lain di bursa saham.

Pada umumnya, keterlambatan pelaporan keuangan terbagi menjadi tiga kriteria, yaitu:

(1) Preliminary lag: Interval antara berakhirnya tahun fiskal sampai dengan tanggal diterimanya laporan keuangan pendahulu oleh pasar modal.

(2) Auditor's Report lag: Interval antara berakhirnya tahun fiskal sampai dengan tanggal yang tercantum dalam laporan auditor,

(3) Total lag: Interval antara berakhirnya tahun fiskal sampai dengan tanggal diterimanya laporan ke tahunan publikasi oleh pasar.

Dalam penelitian ini penulis menggunakan perhitungan dengan menggunakan kriteria Auditor's Report Lag, yang dapat dihitung dengan rumus:

"Audit Delay = Tanggal laporan auditor - Tanggal laporan keuangan"

\section{Opini Auditor}

Menurut Apriliane (2015) opini audit merupakan pendapat atas kewajaran laporan keuangan yang diauditnya. Menurut Mulyadi (2002:20), ada lima tipe pendapat laporan audit yang diterbitkan oleh auditor:

Berdasarkan SPAP (Standar Profesional Akuntan Publik) 2013, opini audit terdiri dari 5 macam, yaitu

1) Pendapat wajar tanpa pengecualian (Unqualified opinion)

2) Pendapat wajar tanpa pengecualian dengan bahasa penjelasan (Unqualified Opinion Report with Explanatory language)

3) Pendapat wajar dengan pengecualian (Qualified Opinion)

4) Pendapat tidak wajar (Adverse Opinion)

5) Pernyataan tidak memberikan pendapat (Disclaimer of Opinion)

Opini audit didefenisikan sebagai pernyataan pendapat yang diberikan oleh auditor dalam menilai kewajaran penyajian laporan keuangan perusahaan yang diauditnya. Pengukuran variabel opini audit menggunakan variabel dummy, nilainya adalah 1 dan 0 . Jika perusahaan klien mendapat opini selain wajar tanpa pengecualian maka diberikan nilai 0 . Sedangkan jika perusahaan klien menerima opini wajar tanpa pengecualian, maka diberikan nilai 1.

\section{Profitabilitas}

Menurut Lapinayanti dan Budhiarta (2018:1067) profitabilitas merupakan kemampuan suatu perusahaan dalam menghasilkan keuntungan/laba. Profitabilitas adalah rasio untuk mengukur kemampuan perusahaan untuk menghasilkan keuntungan pada tingkat penjualan, aset dan modal saham tertentu. Profitabilitas adalah kemampuan perusahaan untuk menghasilkan keuntungan (Murhadi, 2013).

Kartika (2011) menyatakan perusahaan yang mampu menghasilkan profit akan cenderung mengalami audit delay yang lebih pendek, sehingga good news tersebut dapat segera disampaikan kepada para investor dan pihak-pihak yang berkepentingan lainnya. Sebagai dasar pemikiran bahwa tingkat keuntungan dipakai sebagai salah satu cara untuk menilai keberhasilan efektivitas perusahaan, yang tentu saja berkaitan dengan hasil akhir dari berbagai kebijakan dan keputusan perusahaan yang telah dilaksanakan oleh perusahaan dalam periode berjalan. Perusahaan yang profitable memiliki insentif untuk menginformasikan ke publik kinerja unggul mereka dengan mengeluarkan laporan tahunan secara cepat.

Indikator yang digunakan untuk mengetahui tingkat profitabilitas suatu perusahaan dalam penelitian ini adalah return on asset (ROA).

\section{Ukuran perusahaan}

Menurut Chasanah (2016) besar kecilnya ukuran perusahaan dapat didasarkan pada total nilai aset, total penjualan, kapitalisasi pasar, jumlah tenaga kerja dan sebagainya. Semakin besar nilai item-item tersebut maka semakin besar pula ukuran perusahaan itu. 
Turrel dan Tucay (2016) menyatakan biasanya perusahaan besar tepat waktu dalam menyampaikan laporan keuangannya karena perusahaan besar cenderung memiliki sistem kontrol internal yang kuat sehingga auditor menghabiskan lebih sedikit waktu dalam melakukan tes kontrol. Oleh karena itu meminimalkan audit delay dan memungkinkan perusahaan untuk segera melaporkan kepada publik

Perusahaan dapat diklasifikasikan sebagai perusahaan besar atau kecil didasari oleh indikator yang mempengaruhinya. Menurut Werner R. Murhadi (2013) Ukuran perusahaan (firm size) diukur dengan mentrasformasikan total aset yang dimiliki perusahaan ke dalam bentuk logaritma natural. Ukuran perusahaan diproksikan dengan menggunakan Log Natural Total Aset dengan tujuan agar mengurangi fluktuasi data yang berlebih.

Dengan menggunakan log natural, jumlah aset dengan nilai ratusan miliar bahkan triliun akan disederhanakan, tanpa mengubah proporsi dari jumlah aset yang sesungguhnya.

$$
\text { "Ukuran perusahaan = Ln (Total Aset)" }
$$

\section{Pengaruh Opini Auditor Terhadap Audit Delay}

Opini auditor merupakan pendapat atas kewajaran laporan keuangan (Kurniawan \& Herry 2015). Tujuan utama proses audit menurut IAI (2009) adalah untuk memberikan opini atas audit laporan keuangan perusahaan. Opini selain wajar tanpa pengecualian (unqualified opinion) merupakan opini yang tidak pernah diharapkan oleh manajemen perusahaan.

Menurut Arens,dkk (2008:427) jika auditor meyakini adanya cukup bukti tetapi menyimpulkan bahwa laporan keuangan tidak disajikan secara wajar maka perusahaan mempunyai pilihan untuk merevisi laporan tersebut agar untuk memenuhi sesuai dengan aturan akuntansi yang berlaku.

Hal ini berarti manajemen perusahaan akan membuat laporan keuangan yang baru lagi hingga menunjukkan opini yang diharapkan manajemen dan auditor sendiri. Waktu yang digunakan untuk membuat laporan keuangan baru akan memperlambat pengungkapan laporan keuangan ke hadapan publik.

Semakin lama pengungkapan laporan keuangan maka akan audit delay nya akan semakin panjang.Yang berarti, jika pendapat atau opini suatu auditor merupakan pendapat tidak wajar maka audit delay akan semakin lama.

\section{Pengaruh Profitabilitas Terhadap Audit Delay}

Profitabilitas merupakan kemampuan suatu perusahaan dalam menghasilkan keuntungan/laba. Profitabilitas adalah rasio untuk mengukur kemampuan perusahaan untuk menghasilkan keuntungan pada tingkat penjualan, aset dan modal saham tertentu.

Menurut Afify dalam Hooper \& Devi (2011:118) perusahaan yang mempunyai tingkat profitabilitas yang tinggi membutuhkan waktu untuk mengaudit laporan keuangan lebih cepat dikarenakan keharusan menyampaikan kabar baik secepatnya terhadap publik. Perusahaan yang profitabilitas yang tinggi memiliki insentif untuk menginformasikan ke publik kinerja unggul mereka dengan mengeluarkan laporan tahunan secara cepat.

Perusahaan yang mengalami kerugian akan membuat profitabilitas menurun dan akan cenderung lebih hati-hati dalam melakukan proses audit sehingga meminta auditor untuk mengatur waktu audit lebih lama dibandingkan biasanya. Dengan demikian auditor yang menghadapi perusahaan yang mengalamikerugian memiliki respon yang lebih berhati-hati. Sehingga menyebabkan pihak perusahaan mempublikasikan laporan keuangannya lebih lama.

Maka, semakin tinggi tingkat profitabilitas suatu perusahaan maka semakin pendek audit delaynya dan semakin rendah profitabilitas suatu perusahaan akan menyebabkan audit delay yang lebih panjang.

\section{Pengaruh Ukuran Perusahaan Terhadap Audit Delay}

Ukuran perusahaan merupakan suatu indikator yang menunjukkan kondisi atau karakteristik perusahaan dimana terdapat beberapa parameter yang dapat digunakan untuk menentukkan ukuran (besar atau kecilnya) suatu perusahaan. 
Menurut Dyer dan Mc Hugh (1975), perusahaan yang berukuran besar lebih konsisten untuk tepat waktu dibandingkan perusahaan kecil dalam menginformasikan laporan keuangannya.Perusahaan besar diduga akan menyelesaikan proses auditnya lebih cepat dibandingkan perusahaan kecil. Hal ini disebabkan oleh beberapa faktor yaitu manajemen perusahaan yang berskala besar cenderung diberikan insentif untuk mengurangi audit delay dikarenakan perusahaan-perusahaan tersebut dimonitor secara ketat oleh investor, pengawas permodalan dari pemerintah. Pihak-pihak ini sangat berkepentingan terhadap informasi yang termuat dalam laporan keuangan.

Turrel dan Tucay (2016) menyatakan biasanya perusahaan besar tepat waktu dalam menyampaikan laporan keuangannya karena perusahaan besar cenderung memiliki sistem kontrol internal yang kuat sehingga auditor menghabiskan lebih sedikit waktu dalam melakukan tes kontrol.

Pengaruh ini ditunjukkan oleh ukuran perusahaan yang diukur berdasarkan besar nilai aktiva. Maka semakin besar perusahaan maka semakin besar nilai aktiva, yang juga berarti dengan semakin besar nilai aktiva perusahaan, maka semakin pendek audit delay dan sebaliknya.

\section{Hipotesis}

Hipotesis merupakan hubungan yang diduga secara logis antara dua variabel atau lebih yang dapat diuji secara empiris. Sebagai hasil kesimpulan sementara dari penelitian ini, maka hipotesis yang dirumuskan dalam penelitian ini adalah:

$\mathrm{H}_{1}$ : Opini auditor berpengaruh negatif terhadap audit delay pada perusahaan pertambangan yang terdaftar di BEI tahun 2016-2018

$\mathrm{H}_{2}$ : Profitabilitas berpengaruh negatif terhadap audit delay pada perusahaan pertambangan yang terdaftar di BEI tahun 2016- 2018

$\mathrm{H}_{3}$ : Ukuran perusahaan berpengaruh negatif terhadap audit delay pada perusahaan pertambangan yang terdaftar di BEI tahun 2016-2018

\section{METODE PENELITIAN}

\section{Populasi dan Sampel}

Populasi dalam penelitian ini adalah Perusahaan pertambangan tahun 2016-2018 yang terdaftar di Bursa Efek Indonesia. Teknik pengambilan sampel dalam penelitian ini menggunakan metode purposive sampling. Jumlah sampel dalam penelitian ini sebanyak 11 perusahaan pertambangan yang terdaftar di Bursa Efek Indonesia. Periode pengamatan dilakukan selama 3 tahun yaitu 2016-2018. Oleh karena itu, total sampel sebanyak 36 × $3=108$.

\section{Operasionalisasi variabel penelitian}

\section{a. Audit Delay}

Audit delay adalah rentang waktu lamanya hari dalam menyelesaikan proses audit oleh auditor independen dari tanggal tutup buku pada tanggal 31 Desember sampai dengan tanggal yang tercantum dalam laporan auditor independen (Apriliane 2015). Variabel ini diukur secara kuantitatif dalam jumlah hari.

Audit Delay $=$ Tanggal Laporan Audit - Tanggal Laporan Keuangan

b. Opini Auditor

Opini audit yaitu opini yang terdapat dalam laporan audit yang merupakan pernyataan pendapat auditor terhadap kewajaran laporan keuangan berdasarkan atas audit yang dilaksanakan dengan menggunakan standar auditing dan atas temuan-temuannya.Ada empat jenis opini yang diberikan oleh auditor kepada perusahaan. Dalam penelitian ini opini auditor dibagi menjadi dua, yaitu opini selain wajar tanpa pengecualian (selain unqualified opinion) dan opini wajar tanpa pengecualian (unqualified opinion). Variabel ini diukur dengan dummy yaitu untuk opini selain wajar tanpa pengecualian (selain unqualified opinion) diberi kode dummy 0 dan untuk opini wajar tanpa pengecualian (unqualified opinion) diberi kode 1.

c. Profitabilitas 
Profitabilitas adalah kemampuan perusahaan untuk menghasilkan keuntungan (Murhadi, 2013). Indikator yang digunakan dalam penelitian ini yaitu pengembalian atas aktiva (return on assets), yang menggambarkan sejauhmana kemampuan aset-aset yang dimiliki perusahaan bisa menghasilkan laba. Secara matematis rumus untuk menghitung ROA sebagai berikut (Tendelilin, 2018:240) :

$$
\text { Return On Assets }=\frac{\text { Laba bersih }}{\text { Total Aktiva }} \times 100 \%
$$

d. Ukuran Perusahaan

Ukuran perusahaan adalah besar kecilnya suatu perusahaan yang diukur dengan menggunakan total aset.Menurut Werner R. Murhadi (2013) Ukuran perusahaan (firm size) diukur dengan mentrasformasikan total aset yang dimiliki perusahaan ke dalam bentuk logaritma natural. Dapat dituliskan dengan rumus sebagai berikut:

\section{Teknik Analisis Data}

Teknik analisis yang digunakan dalam penelitian ini adalah persamaan regresi linear berganda yagn dirumuskan sebagai berikut:

$$
\hat{\mathrm{Y}}=\mathrm{bo}+\mathrm{b} 1 \mathrm{X} 1+\mathrm{b} 2 \mathrm{X} 2+\mathrm{b} 3 \mathrm{X} 3+\varepsilon
$$

Keterangan:

$$
\begin{aligned}
& \hat{\mathrm{Y}}=\text { Audit Delay } \\
& \mathrm{X} 1=\text { Opini auditor } \\
& \mathrm{X} 2=\text { Profitabilitas } \\
& \mathrm{X} 3=\text { Ukuran Perusahaan } \\
& \mathrm{b} 0=\text { Intersep } \\
& \mathrm{b} 1, \mathrm{~b} 2, \ldots \mathrm{b} 3=\text { koefesien regresi } \\
& \varepsilon=\text { standar eror }
\end{aligned}
$$

\begin{tabular}{|c|c|c|c|c|c|c|c|c|}
\hline \multicolumn{9}{|c|}{ Descriptive Statistics } \\
\hline & $\mathrm{N}$ & Range & $\begin{array}{c}\text { Minim } \\
\text { um }\end{array}$ & $\begin{array}{c}\text { Maximu } \\
\mathrm{m}\end{array}$ & Sum & \multicolumn{2}{|c|}{ Mean } & $\begin{array}{c}\text { Std. } \\
\text { Deviation }\end{array}$ \\
\hline & $\begin{array}{c}\text { Statist } \\
\text { ic }\end{array}$ & $\begin{array}{c}\text { Statisti } \\
\mathrm{c}\end{array}$ & $\begin{array}{c}\text { Statisti } \\
\mathrm{c}\end{array}$ & Statistic & $\begin{array}{l}\text { Statist } \\
\text { ic }\end{array}$ & $\begin{array}{l}\text { Statist } \\
\text { ic }\end{array}$ & $\begin{array}{c}\text { Std. } \\
\text { Error }\end{array}$ & Statistic \\
\hline Delay & 108 & 205 & 0 & 205 & 8678 & 80,35 & 2,926 & 30,403 \\
\hline Opini & 108 & 1,00 &, 00 & 1,00 & $\begin{array}{r}104,0 \\
0\end{array}$ & ,9630 &, 01826 & , 18973 \\
\hline Roa & 108 & 76,32 & $-30,76$ & 45,56 & $\begin{array}{r}518,9 \\
4\end{array}$ & $\begin{array}{r}4,805 \\
0\end{array}$ & $\begin{array}{r}1,1568 \\
2\end{array}$ & 12,02200 \\
\hline Size & 108 & 15,67 & 16,29 & 31,96 & $\begin{array}{r}2948, \\
93\end{array}$ & $\begin{array}{r}27,30 \\
49\end{array}$ & ,37762 & 3,92434 \\
\hline $\begin{array}{l}\text { Valid N } \\
\text { (listwise) }\end{array}$ & 108 & & & & & & & \\
\hline
\end{tabular}

\section{HASIL PENELITIAN DAN PEMBAHASAN}

\section{Statistik Deskriptif}

Tabel 1 Statistik Deskriptif

\section{Sumber: Hasil Output SPSS 24 (Data diolah)}

Audit delay memiliki Nilai maksimum 205 hari pada perusahaan Apexindo Duta Pratama Tbk pada tahun 2017. Dan nilai minimun 0 hari pada perusahaan Timah Tbk tahun 2017 dan 2018. 
Opini auditor diukur menggunakan dummy maka nilai maksimum opini auditor hanyalah 1 dan nilai minimumnya 0 .

Ukuran perusahaan Nilai maksimum Ln Total Asset 31,96 pada perusahaan Medco Energi Internasional Tbk pada tahun 2018. Dan nilai minimum Ln Total Asset 16,29 pada perusahaan Timah Tbk di tahun 2017. Profitabilitas (ROA) Nilai maksimum ROA 45,56 pada perusahaan Bayan Resources Tbk pada tahun 2018 dan nilai minimumnya -30,76 yang bernilai negatif, yang berarti perusahaan mengalami kerugian, hal ini terjadi pada perusahaan Bara Jaya Internasional Tbk di tahun 2017.

\section{Pengujian Hipotesis}

Uji t dilakukan untuk mengetahui hubungan antara variabel-variabel independen terhadap variabel dependen secara parsial. Dengan menggunakan tingkat signifikan $(\alpha=5 \%)$, jika nilai signifikan $\mathrm{t}>0,05$ maka hipotesis ditolak, artinya tidak terdapat pengaruh yang signifikan secara parsial dari variabel independen terhadap variabel dependen. Sebaliknya, jika nilai signifikan $\mathrm{t}<$ 0,05 maka hipotesis diterima, artinya terdapat pengaruh yang signifikan secara parsial dari variabel independen dan variabel dependen. Hasil output SPSS adalah sebagai berikut:

Tabel 2 Hasil Uji t

\begin{tabular}{|c|c|c|c|c|c|c|}
\hline \multicolumn{7}{|c|}{ Coefficients $^{\mathrm{a}}$} \\
\hline \multirow{2}{*}{\multicolumn{2}{|c|}{ Model }} & \multicolumn{2}{|c|}{ Unstandardized Coefficients } & $\begin{array}{l}\text { Standardized } \\
\text { Coefficients }\end{array}$ & \multirow[b]{2}{*}{$\mathrm{t}$} & \multirow[b]{2}{*}{ Sig. } \\
\hline & & $\mathrm{B}$ & Std. Error & Beta & & \\
\hline \multirow[t]{4}{*}{1} & (Constant) & 48,386 & 21,927 & & 2,207 &, 030 \\
\hline & Opini & $-26,967$ & 12,741 &,- 168 & $-2,117$ & 037 \\
\hline & Profit & $-1,264$ & ,202 &,- 500 & $-6,261$ &, 000 \\
\hline & Size & 2,344 & ,618 &, 303 & 3,790 &, 000 \\
\hline
\end{tabular}

a. Dependent Variable: delay

Sumber : Hasil Output

Berdasarkan tabel diatas, nilai koefisien opini auditor -2,117 dengan tingkat signifikan $0,037<0,05$, yang berarti bahwa variabel opini auditor berpengaruh negatif dan signifikan terhadap audit delay pada perusahaan pertambangan yang terdaftar di Bursa Efek Indonesia.

Variabel profitabilitas memiliki nilai koefisien profitabilitas sebesar -6,261 dengan tingkat signifikan $0,000<0,05$, yang berarti berpengaruh negatif dan signifikan terhadap audit delay pada perusahaan pertambangan yang terdaftar di Bursa Efek Indonesia,

Variabel ukuran perusahaan memiliki nilai koefisien ukuran perusahaan sebesar 3,790 dengan tingkat signifikansi $0,000<0,05$, yang berarti berpengaruh positif dan signifikan terhadap audit delay pada perusahaan pertambangan yang terdaftar di Bursa Efek Indonesia,

\section{Opini Auditor terhadap Audit Delay}

Berdasarkan hasil olah data statistik dapat dilihat bahwa nilai t hitung sebesar -2,117 lebih kecil dari t tabel yaitu 0,67686 dengan tingkat signifikansi 0,037 lebih kecil dari tingkat keyakinan $0,05(0,037<0,05)$, hal ini menunjukkan opini auditor berpengaruh negatif dan signifikan terhadap audit delay. Dengan demikian hipotesis H1 diterima.

Hal tersebut berarti bahwa perusahaan yang laporan keuangannya memperoleh opini Wajar Tanpa Pengecualian (unqualified opinion) akan mengalami audit delay yang lebih pendek dari pada perusahaan yang laporan keuangannya memperoleh opini selain Wajar Tanpa Pengecualian. Hal tersebut dikarenakan opini WDP (Wajar Dengan Pengecualian) atau selain Wajar Tanpa Pengecualian dianggap sebagai sinyal adanya suatu masalah. Hal itu menandakan bahwa ada sesuatu yang tidak biasa atau serius telah terjadi, sehingga dibutuhkan waktu yang lebih lama dalam pelaksanaan audit untuk menyelesaikan masalah tersebut, sehingga auditor harus mencari bukti audit yang kompeten lebih banyak yang akhirnya dapat memperpanjang waktu audit. Audit delay yang lebih panjang dialami oleh perusahaan yang menerima opini WDP karena proses 
pemberian opini tersebut melibatkan negosiasi dengan klien, konsultasi dengan partner audit yang lebih senior, dan perluasan lingkup audit

Hasil ini sejalan dengan teori Arens, dkk (2008:472) yang menyatakan jika auditor meyakini adanya cukup bukti tetapi menyimpulkan bahwa laporan keuangan tidak disajikan secara wajar maka perusahaan mempunyai pilihan untuk merevisi laporan tersebut agar untuk memenuhi sesuai dengan aturan akuntansi yang berlaku.

Hal ini berarti manajemen perusahaan akan membuat laporan keuangan yang baru lagi hingga menunjukkan opini yang diharapkan manajemen dan auditor sendiri. Waktu yang digunakan untuk membuat laporan keuangan baru akan memperlambat pengungkapan laporan keuangan ke hadapan publik.

Semakin lama pengungkapan laporan keuangan maka akan audit delay nya akan semakin panjang. Yang berarti, jika pendapat atau opini suatu auditor merupakan pendapat tidak wajar maka audit delay akan semakin lama.

Hasil penelitian ini didukung oleh penelitian Anthusian Indra Kurniawan \& Herry Laksito (2015) dan Asli Turrel \& Ferhan Emir Tuncay (2016) yang menyatakan opini auditor berpengaruh signifikan terhadap audit delay. Dan menolak hasil penelitian Moch. Sulthony (2012) yang menyatakan opini auditor tidak berpengaruh terhadap audit delay.

\section{Pengaruh Profitabilitas Terhadap Audit Delay}

Berdasarkan hasil olah data statistik dapat dilihat bahwa profitabilitas yang diukur dengan ROA menunjukkan nilai t hitung sebesar -6,261 lebih kecil dari t tabel yaitu 0,67686 dengan tingkat signifikansi 0,000 lebih kecil dari tingkat keyakinan 0,05. Hal ini berarti bahwa profitabilitas berpengaruh negatif dan signifikan terhadap audit delay. Dengan demikian hipotesis $\mathrm{H} 2$ diterima.

Dengan demikian perusahaan yang memiliki profitabilitas yang tinggi akan mengalami audit delay yang lebih cepat dibandingkan perusahaan dengan profitabilitas yang rendah.

Hasil penelitian ini didukung oleh teori Afify dalam Hooper \& Devi (2011:118) yang menyatakan bahwa perusahaan yang mempunyai tingkat profitabilitas yang tinggi membutuhkan waktu untuk mengaudit laporan keuangan lebih cepat dikarenakan keharusan menyampaikan kabar baik secepatnya terhadap publik. Tingkat profitabilitas yang semakin tinggi dapat pula berpengaruh terhadap audit delay karena adanya tuntutan dari stakeholder untuk melakukan manajemen laba yang membuat waktu audit menjadi bertambah.

Afify juga memberikan alasan bahwa auditor yang menghadapi perusahaan yang mengalami kerugian memiliki respon yang lebih berhati-hati karena risiko bisnis terkait. Hasil penelitian ini mendukung hasil penelitian Ni Made Mega Lapinayanti \& I Ketut Budiartha (2018) yang menyatakan bahwa profitabilitas berpengaruh terhadap audit delay dan menolak hasil penelitian Anthusian Indra Kurniawan, \& Herry Laksito (2015) dan Khalid Alkhatib \& Qais Marji (2012) yang menyatakan bahwa profitabilitas tidak berpengaruh terhadap audit delay.

\section{Pengaruh Ukuran Perusahaan Terhadap Audit Delay}

Berdasarkan hasil olah data statistik dapat dilihat bahwa ukuran perusahaan diukur dengan Ln asset menunjukkan nilai t hitung sebesar 3,790 lebih besar dari t tabel yaitu 0,67686 dengan tingkat signifikansi 0,000 lebih kecil dari tingkat keyakinan 0,05. Hal ini berarti bahwa ukuran perusahaan berpengaruh positif dan signifikan terhadap audit delay. Dengan demikian hipotesis $\mathrm{H} 3$ ditolak.

Hal ini disebabkan karena banyaknya transaksi yang lebih kompleks di perusahaan dengan total aset besar sehingga proses audit yang ditempuh semakin panjang. Dengan demikian perusahaan kecil memiliki audit delay yang lebih singkat dibandingkan perusahaan besar.

Hasil ini menolak teori yang disampaikan oleh Subroto (2014:35) yang menyatakan bahwa perusahaan-perusahaan besar cenderung cepat dalam menyampaikan laporan keuangan, karena perusahaan-perusahaan besar cenderung menarik perhatian publik dan pemerintah untuk melakukan berbagai regulasi.

Pada kenyataannya karena sampel merupakan perusahaan dari Bursa Efek Indonesia maka sudah sewajar nya diawasi oleh pemerintah maupun badan regulasi lainnya, baik itu perusahaan 
dengan total aset yang kecil maupun yang besar. Maka perhatian dari publik maupun pemerintah terhadap perusahaan besar tidak dapat dijadikan tolak ukur bagi perusahaan dengan total aset besar untuk mempercepat penyampaian laporan keuangannya.

Hasil penelitian ini didukung oleh penelitian Asli Turrel \& Ferhan Emir Tuncay (2016) yang menyatakan bahwa ukuran perusahaan berpengaruh terhadap audit delay. Dan menolak hasil penelitian yang dilakukan oleh Khalid Alkhatib \& Qais Marji (2012) dan Moch. Sulthony (2012) yang menyatakan bahwa ukuran perusahaan tidak berpengaruh terhadap audit delay.

\section{Pengaruh Opini Auditor, Profitabilitas dan Ukuran Perusahaan Terhadap Audit Delay}

Berdasarkan hasil uji $\mathrm{F}$ pada tabel 4.13, $\mathrm{F}_{\text {hitung }} 19,171>\mathrm{F}_{\text {tabel }} 2,69$ dan signifikan 0,000 <

0,05 . Hal ini berarti bahwa variabel opini auditor, profitabilitas dan ukuran perusahaan secara simultan berpengaruh signifikan pada variabel dependen audit delay pada perusahaan pertambangan yang terdaftar di Bursa Efek Indonesia (BEI).

Besarnya aktiva perusahaan, opini auditor terhadap laporan keuangan dan kemampuan perusahaan untuk menghasilkan laba tersebut secara bersama-sama mempengaruhi audit delay.

\section{KESIMPULAN}

a. Opini auditor secara parsial berpengaruh negatif dan signifikan terhadap audit delay. Hal ini berarti perusahaan yang mendapat opini wajar tanpa pengecualian (Unqualified Opinion) maka audit delay nya akan semakin rendah atau singkat.

b. Profitabilitas secara parsial berpengaruh negatif dan signifikan terhadap audit delay. Hal ini berarti semakin tinggi tingkat profitabilitas, maka audit delay akan semakin menurun atau singkat.

c. Ukuran perusahaan secara parsial berpengaruh positif dan signifikan terhadap audit delay. Hal ini menunjukkan semakin tinggi ukuran perusahaan, maka audit delay akan semakin meningkat atau semakin lama.

\section{DAFTAR PUSTAKA}

Almawadi, Issa. 2017. Sektor Pertambangan dan Agrikultur Pimpin Perubahan Laba Emiten Q12017.https://www.bareksa.com/id/text/2017/05/18/sektor-pertambangan-agrikulturpimpin-pertumbuhan-laba-emiten-q1-2017/15548/news, diakses tanggal 07 Okt 2019.

Arens A. A, Elder J. Landar dan Beasley S. Mark. 2008. Auditing dan Jasa Assurance Pendekatan Terintegrasi Edisi Keduabelas, Jilid 2. Jakarta : Penerbit Erlangga.

Apriliane, Malinda D. 2015. Analisis Faktor-Faktor Yang Mempengaruhi Audit Delay (Studi Empiris Pada Perusahaan Pertambangan Yang Terdaftar Di Bursa Efek Indonesia Tahun 2008 - 2013). Fakultas Ekonomi. Universitas Yogyakarta: Yogyakarta.

Bursa Efek Indonesia. 2019. www.idx.co.id

Chasanah Uswatun. 2016. Pengaruh Ukuran Perusahaan, Reputasi Auditor, Profitabilitas, Dan Solvabilitas Terhadap Audit Delay (Studi Empiris pada Perusahaan Manufaktur yang Terdaftar di Bursa Efek Indonesia Tahun 2012-2014). Fakultas Ekonomi Dan Bisnis. Universitas Muhammadiyah Surakarta: Surakarta.

Coki. 2008. Keuntungan dan kerugian dalam investasi saham. https://coki002.wordpress.com/keuntungan-dan-kerugian-dalam-investasi-saham/, diakses tanggal 05 Desember 2019

Devi, S. Susela dan Keith Hooper, ed. 2011. Acounting in Asia. United Kingdom (UK) : Emerald Group Publishing Limited. 
Fanny, Dimas R. 2017. Analisis Faktor-Faktor Yang Mempengaruhi Audit Delay Pada Perusahaan Manufaktur Yang Terdaftar Di Bursa Efek Indonesia Tahun 2013-2015. Fakultas Ekonomi Dan Bisnis Universitas Lampung: Bandar Lampung.

Lestari, Dewi. 2010. Analisis Faktor-Faktor Yang Mempengaruhi Audit Delay: Studi Empiris Pada Perusahaan Consumer Goods Yang Terdaftar Di Bursa Efek Indonesia. Skripsi. Fakultas Ekonomi. Universitas Diponegoro: Semarang.

Ghozali, Iman. 2018. Aplikasi Analisis Multivariate Dengan Program IBM SPSS 25. Semarang: Badan Penerbit-Undip.

Investasiku co.id. 2017. Ini Antara Emiten Berkinerja Positif dan Perusahaan Belum Disiplin.http://investasiku.co.id/blog/blog id/ini-antara-emiten-berkinerja-positif-danperusahaan-belum-disiplin-2017-05-19-09-04-11, akses 05 Desember 2019.

Kasmir. 2014. Analisis Laporan Keuangan. Jakarta: Raja Grafindo Persada.

Kartika, Andi. 2011. Faktor-Faktor Yang Mempengaruhi Audit Delay Pada Perusahaan Manufaktur Yang Terdaftar Di Bei. Dinamika Keuangan dan Perbankan, Hal: 152 - 171 Vol. 3, No. 2.

Kurniawan, Anthusian I dan Herry Laksito.2015. Analisis Faktor-Faktor Yang Mempengaruhi Audit Delay (Studi Empiris pada Perusahaan LQ 45 yang terdaftar di Bursa Efek Indonesia Periode Tahun 2010-2013). DIPONEGORO JOURNAL OF ACCOUNTING Volume 4, Nomor 3, Tahun 2015, Halaman 1-13 http://ejournals1.undip.ac.id/index.php/accounting ISSN (Online): 2337-3806.

Lapinayanti, Ni Made M dan I Ketut Budiartha. 2018. Pengaruh Profitabilitas dan Leverage Pada Audit Delay dengan Ukuran Perusahan Sebagai Pemoderasi. E-Jurnal Akuntansi Universitas Udayana Vol.23.2. Mei (2018): 1066-1092 ISSN: 2302-8556 DOI: https://doi.org/10.24843/EJA.2018.v23.i02.p10.

Mulyadi. 2002. Auditing Edisi ke-6 Cetakan ke-1. Jakarta: Salemba Empat

Murhadi, R. Werner. 2013. Analisis Laporan Keuangan Proyeksi dan Valuasi Saham. Jakarta: Salemba Empat.

Parospati, Giras. 2016. Telat Sampaikan Laporan Keuangan BEI Suspensi Saham 18 Perusahaan. https://www.cnnindonesia.com/ekonomi/20160630145045-92-142141/telat-sampaikanlapkeu-bei-suspensi-saham-18-perusahaan, diakses tanggal 01 Oktober 2019.

Peraturan Otoritas Jasa Keuangan (OJK) Nomor 29/POJK.04/2016

Peraturan otoritas jasa keuangan nomor 53 /pojk.04/2017

Prameswari, Afina Survita dan Hanny Rahmawati Yustrianthe. 2015. Analisis Faktor - Faktor Yang Memengaruhi Audit Delay (Studi Empiris Pada Perusahaan Manufaktur Yang Terdaftar Di Bursa Efek Indonesia). Jurnal Akuntansi/Volume XIX, No. 01, Januari 2015: 50-67, Sekolah Tinggi Ilmu Ekonomi YAI Jakarta.

Shultoni, Moch. 2013. Determinan Audit Delay Dan Pengaruhnya Terhadap Reaksi Investor (Studi Empiris pada Perusahaan yang Listing di BEI Tahun 2007-2008). Jurnal Akuntansi Aktual, Vol. 2, Nomor 1, Januari 2013, hlm. 9-18.

Situmorang, Rapi. 2017. Faktor-faktor yang Berpengaruh Terhadap Audit Delay Pada Consumer Goods Industry yang Terdaftar di Bursa Efek Indonesia Tahun 2013-2016. Skripsi. Fakultas Ekonomi. Universitas Katolik Santo Thomas: Medan. 
Subroto, Bambang. 2014. Pengungkapan Wajib Perusahaan Publik: Kajian Teori dan Empiris. Malang: UB Press.

Sugiyono. 2017. Metode Penelitian Kombinasi (Mixed Methods). Bandung: Alfabeta

Super, O. Sagin dan Shil Nikkhil Candra. 2019. Effect of Audit Delay on the Financial Statements. Sumerianz Journal of Economics and Finance, 2019, Vol. 2, No. 4, pp. 37-43 ISSN(e): 2617-6947, ISSN(p): 2617-7641.Website: https://www.sumerianz.com.

Tandiotong, Mathius. 2016. Kualitas Audit Dan Pengukurannya. Bandung: Alfabeta

Tendelilin, Eduardus. 2018. Analisis Investasi dan Manajemen Portofolio. Yogyakarta: BPFE

Turel, Asli \& Tuncay, Ferhan. 2016. An Empirical Analysis Of Audit Delay In Turkey. Annales Universitatis Apulensis Series Oeconomica. 18. 97-105.

Willem, Kurniawan. 2018. Saham-saham Sektor Pertambangan Masih Jadi Jawara Bursa. https://investasi.kontan.co.id/news/saham-saham-sektor-tambang-masih-jadi-jawarabursa, diakses tanggal 07 Oktober 2019. 